\title{
On Exploration and Practice of Application-Oriented Talent Cultivation System of English Related Majors in Local Normal Universities in China
}

\author{
$\mathrm{Bo} \mathrm{Xu}^{1}$ \\ ${ }^{1}$ School of Foreign Languages, Leshan Normal University, Sichuan Province, China \\ Correspondence: Bo Xu, School of Foreign Languages, Leshan Normal University, Sichuan Province, China
}

Received: September 19, 2019 Accepted: October 29, 2019 Online Published: October 31, 2019

doi: 10.5539/elt.v12n11p113 URL: https://doi.org/10.5539/elt.v12n11p113

\begin{abstract}
Recently, many local normal universities have been carrying out transformation and development project. Leshan Normal University, a local normal university, is prone to change traditional talents cultivation mode. By taking LSNU as an example, this paper attempts to make an exploration on constructing application-oriented talents training system through reconstructing application-oriented talents cultivation system, constructing application-oriented course system, enhancing practice education and training double-qualified teachers.
\end{abstract}

Keywords: application-oriented talent cultivation system, English related majors, Local Normal Universities

\section{Introduction}

On October $26^{\text {th }} 2017$, the Ministry of Education in China issued implementation measures for teachers' major certification in universities and colleges. The Ministry of Education issued its key points of work which will implement teachers' major certification with a high starting point and high standard. Sichuan province will also implement the teachers' major certification.

In January, 2018, the Ministry of Education issued National Standard for Teaching Quality of Undergraduate major, which specified connotation, disciplinary foundations and orientation of talents cultivation, major scope, training objective, training, teaching staff, teaching conditions and the construction of quality guarantee system. Especially, it speculated the number and structure of teaching staff, background and teaching level of teachers, teachers teaching development qualitatively and quantitatively. It also listed major knowledge system and core course system.

In 2015 Leshan Normal University was granted as the pilot university for Sichuan Provincial Transformation and Development Reform Project. As a local normal university, our aim is to cultivate applied talents. English related majors are composed of English (teachers education), Translation (English-Chinese) and Business English. English was granted as Sichuan provincial key major in 2011. After the New National Standard and Major Certification Measures were issued, it is quite necessary to reform and explore applied talent training system of English related majors.

\section{Literature Review}

Rogers' "student-centered" humanistic educational belief influenced a whole generation of educators. It is a direct application of his "person-centered" non-direction psychotherapy theory. He criticizes traditional education for its emphasis on factual knowledge and puts emphasis on the intrinsic nature of learning, and advocates education that promotes students "self-actualization" and healthy development of their "inner life". Rogers views positive interpersonal relationship, teacher's trust and respect to the student, and "mutual understanding" as the conditions to promote "experiential learning". His humanistic principles can contribute not so much to teaching techniques as to the development of teachers' educational beliefs (Zeng, 2003).

Yun (2012) made an analysis of several main problems occurred in the process of engineering education and performed some exploration and practice of the applied talents cultivation respectively including the positioning of talent cultivation objective, the reformation of talent cultivation mode, the establishment of practice teaching system.

Yang et al. (2017) deemed that, with the progress of the transformation of application-oriented universities, 
newly-founded universities faced a number of problems. Taking Sichuan Tourism University as an example, they conducted a systematic exploration of educational programs in terms of school orientation, program orientation and routes, improvement of curriculum, teaching faculty, and management mechanism innovation.

$\mathrm{Wu}$ and Zhang (2016) held that the principle of "Practice Education"has gradually received attention and the cooperation models between colleges and enterprises have been carried out. They confirmed college-enterprise cooperation being as an important way to cultivate talents in application-oriented colleges, explored the various ways of cooperation in the cognitive practice, professional practice and graduation practice and analyzed the detailed cooperative models and possible problems with the example of English majors with specialty in translation. Last but not the least, possible solution was offered in order to promote the reciprocal development between colleges and enterprises with a solid foundation to cultivate high quality talents.

Wang (2017) held that the basic task of local colleges and universities is to cultivate the application-oriented students with high-quality. Facing the pressing needs of the social transformation and economic development for talents, local colleges and universities were confronted with a long-term issue: with the guidance of application-oriented construction, how to grasp the strategic opportunity of such transformation, optimize the layout, promote the connotation, and form the unique characteristics. With a case study of Taizhou University's 10 -year exploration of application-oriented construction, they intended to study how local colleges and universities may construct a new talent cultivation model with an integration of teaching, producing, study and research, as well as the collaboration between government, enterprise, society, and schools by discussing three core issues, namely, the ambiguous orientation, the disconnection between social needs and the students' knowledge, ability and quality,and the unfavorable collaborative education mechanisms, through the combination of point, line and plane to promote the education reform and practice progressively with special projects.

Zhou et al. (2018) deemed that the starting point of local universities and colleges was to serve local economical construction and social development, with the combination of advantageous discipline and majors with local industrial structure adjustment. They made an exploration and practice of setting the objectives of talents cultivation, curriculum system and practice sector, development and construction of teaching resources, establishment of teaching practice condition so as to cultivate application-oriented talents that can meet the demand of local economic development trend and industrial structure adjustment.

$\mathrm{Hu}$ (2018) found out that universities and colleges in Fujian Province made an exploration and practice of the mode of application-oriented talent training in such aspects as orientation of universities, coordination of relevant industries, cooperation between universities and enterprises, teaching reform, teaching staff training etc. The reform achievement promoted the higher education development in Fujian province which was of great significance to cultivate application-oriented talents with high quality for social and economical development.

Liu (2018) put forward that application-oriented talents training can meet the needs of social and economical development and was an inevitable selection of translation discipline development. He made an exploration and practice of application-oriented translation talents cultivation from the perspective of objective of talents cultivation, curriculum system, teaching staff, practice base and students development.

The American psychologist Abraham H. Maslow, who was one of the leading architects of humanistic psychology, put forward a hierarchy of needs or drives in order to decrease priority or potency but increase sophistication: physiological needs, safety, belonging and love, esteem, and self-actualization. Only when the more primitive needs were met can the individual progress to higher levels in the hierarchy. People reaching self-actualization would have fully realized their potential (form Britannica.com).

For most humanistic psychologists, the concept of the self is a focal key point. In the "personal construct" theory of American psychologist George Kelly and the "self-centred" theory of American psychotherapist Carl Rogers, individuals are said to perceive the world according to their own experiences. This perception affects their personality and leads them to direct their behavior to satisfy the needs of the total self. Rogers stressed that, in the development of an individual's personality, the person strives for "self-actualization (to become oneself), self-maintenance (to keep on being oneself), and self-enhancement (to transcend the status quo)."

Rogers (1969) put forward students-centered education belief. He pointed out that the aim of education was to promote change and learning so as to train a person how to fit into change and how to learn. What he concerned was that all-round development of a person, especially one's inner world. i.e. the development of one's emotion, spirit and values. He also held that such education aim would cultivate a person who could make full potential of oneself, and was constructive, credulous, reasonable, open-minded, creative and with individualized development (cited from Zeng, 2003). 
Therefore, when we put humanistic psychology into talents cultivation for English related majors, the focus is on students-centered and employment-oriented aspect. Under the influence of humanistic psychology, objective of training program is realized through specific graduation requirements, curriculum system, course teaching and evaluation.

In the context of new national standard, teachers' major certification and the transformation of local universities, this paper is based on the cultivation of English, translation and business English major students. It is proper to reconstruct application-oriented talents cultivation system for English related majors; it is appropriate to optimize practice teaching system, reform mode of practice, to construct application-oriented course system on the basis of online courses, to construct three-in-one education system with middle schools, local enterprises and industries and to have practice in teachers development community school so as to train double-professional teachers.

\section{Solutions to and Measures for Constructing Application-oriented Talents Training System}

Based on students-centered education belief, it is necessary and vital to reconstruct application-oriented talents cultivation system, to optimize practice teaching system, to reform mode of practice, to construct application-oriented course system and to train double-professional teachers, which is illustrated in figure 1 as follows:

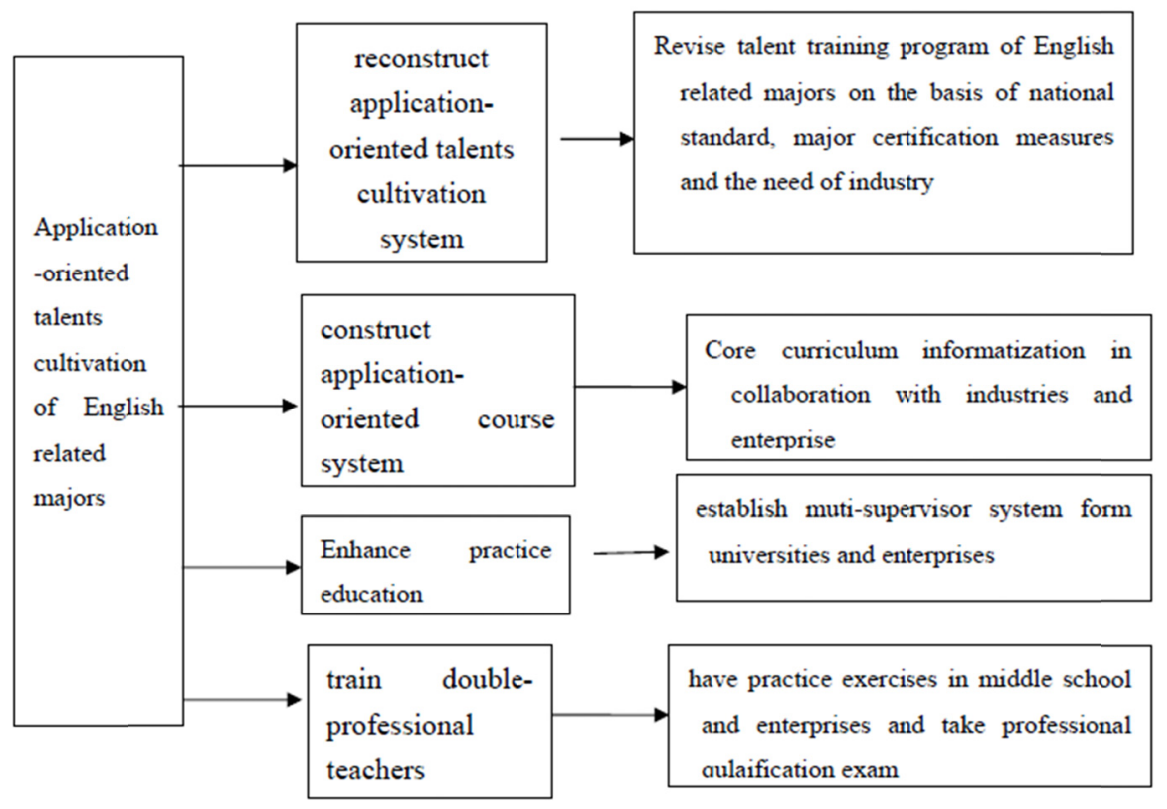

Figure 1. Reconstruct application-oriented talents cultivation system

In the circumstance of national standard and teachers' education certification, it is essential to cooperate with enterprises and industries to revise training program of English related majors. Taking Leshan Normal University as an example, we revise the training program of English major from the perspective of knowledge, ability, quality and coordination development, put emphasis on training students' teachers education skill and teaching ability, clarify that application-oriented talents should have a good command of knowledge, ability and quality, which is to cultivate talents with good command of English basic knowledge,pedagogical content knowledge and teaching skills. Consequently, we put forward tri-objectives for outstanding normal school students: all the students will pass Teacher Qualification Examination, all the students apply for Innovation and Entrepreneurship Training Project for College Students; all the students will apply for post-graduate program.

The project for outstanding normal school students puts emphasis on social practice sector. School of Foreign Languages, LSNU reached a consensus that students can enter middle school English class without any obstacles to listen to middle school English teachers' lecture and discuss relevant matters with them.

It is necessary to construct students-centered education teaching system. Based on humanistic education belief, 
students' individualized development should be taken into consideration in the process of cultivating English majors. Under such system, objective of talents cultivation is achieved through specific graduation requirements. Curriculum system, course teaching and evaluation offer support for graduation requirements and thus improve students' ability. Student-centered and application-oriented education teaching system for English related majors is illustrated in Figure 2 as follows:

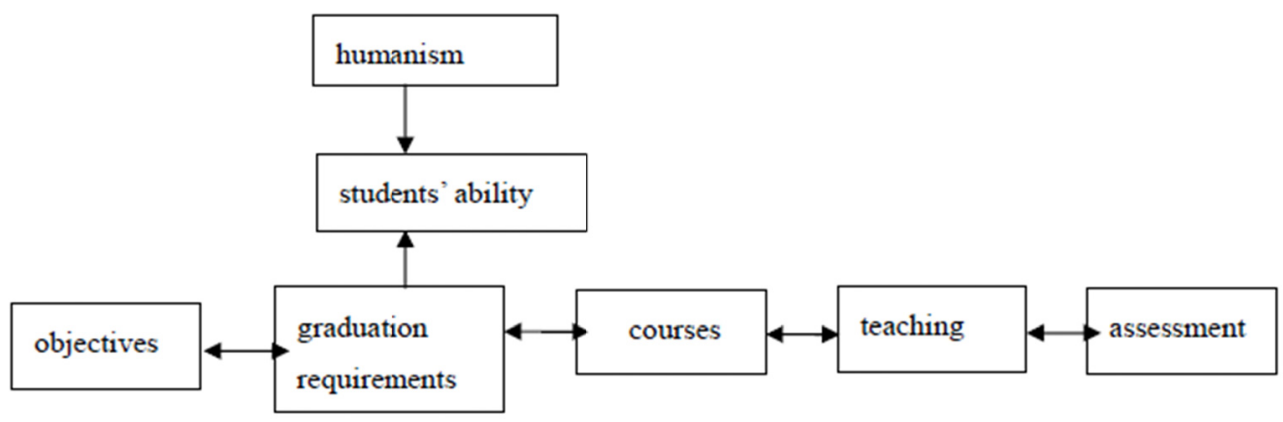

Figure 2. Student-centered and application-oriented education teaching system

English major can cooperate with local education bureau, middle schools and primary schools to establish a community of teacher development. Non-teachers education majors should construct practice base, translation and business English majors go to translation and business and trade firm. It is necessary to carry out muti-supervisor system in which the supervisors are from universities and local government and industry. As is illustrated in Table 1.

Table 1. Optimize practice teaching system and reform mode of practice

\begin{tabular}{lll}
\hline Stage of practice teaching & Mode of collaborative education & Collaborative unit \\
\hline $\begin{array}{l}\text { Practice } \\
\text { practice ) }\end{array}$ & Visit schools, firms and have lectures & $\begin{array}{l}\text { Teachers development community } \\
\text { school, translation firms and foreign } \\
\text { trade enterprises }\end{array}$ \\
Internship exercitation & $\begin{array}{l}\text { Establish language lab and } \\
\text { application-oriented course }\end{array}$ & $\begin{array}{l}\text { Teachers development community } \\
\text { school, translation firms and foreign } \\
\text { trade enterprises }\end{array}$ \\
$\begin{array}{l}\text { Graduation practice (post } \\
\text { switching practice) }\end{array}$ & $\begin{array}{l}\text { Have practice in collaborative unit and } \\
\text { sign employment contract and work there }\end{array}$ & $\begin{array}{l}\text { Teachers development community } \\
\text { school, translation firms and foreign } \\
\text { trade enterprises }\end{array}$ \\
\hline
\end{tabular}

Based on online courses, micro-course, basic education and foreign trade company, application-oriented course is built. It is essential to buy or construct online course, and utilize online courses on Zhihuishu platform( an online course platform) such as English Lexicology, Translation, Business English, Advanced English Writing, Public Speaking and Debating. Core courses of English related majors should be informationized so as to serve application-oriented talents cultivation. As is illustrated in Figure 3. 


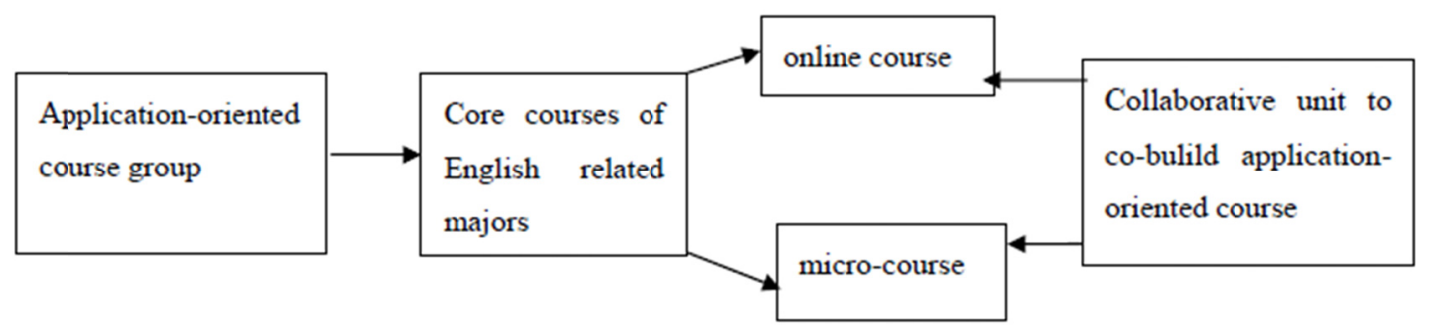

Figure 3. Constructing application-oriented course

Double-professional teachers refer to those who not only have theoretical knowledge but also have practical skills. It is always necessary to train teachers with obvious application-oriented characteristics. To send teachers to enterprises to work is to train teachers' ability to serve the society and application-oriented talents cultivation. At the same time, emphasis should be put on introducing the talent from enterprises. Teachers are encouraged to take professional qualification certificate and proficiency certificate and participate in post-service training and academic exchange. On summer holiday, teachers are sent to enterprises to take shift and have on-the-job placement, translate materials, learn translation, tourism, law, international trade so as to serve economic development in southwest area in China. By doing so, the number of double-professional teachers in School of Foreign Languages, LSNU has amounted to 39 within two years.

The following four main measures are taken to solve the current problems.

First, constructing application-oriented course. Through availing of the opportunity of university, School of Foreign Languages needs to select high-quality course to construct. For example, English Lexicology is constructed as an open online course in Sichuan Province.

Second, carrying out comprehensive reform of teacher education on the basis of English major. Normal students' education and teaching ability should be strengthened and the pass rate of teacher qualification certificate examination needs to be improved. Before Teacher Qualification Certificate Examination, training on Teacher Qualification Certificate Examination (written) as well as interview is implemented by teachers who major in teachers' education. In this way, the pass rate of Test only for English Majors Band 4 (TEM4) has been improved a lot in 2019. The pass rate of Teachers Qualification Certificate Examination has made progress in 2019 too, ranking the fourth place in 15 colleges of LSNU.

Third, strengthening the construction of practice base for Translation Major and Business English Major. To have cooperation with translation firm, foreign trade firm, e-commerce company can strengthen the internship for non-teachers education students. Students skills in translation and business English have been improving thanks to social practice in translation company: Cema Group.

Fourth, Strengthening the training of double-qualified Teachers.Teachers are sent to Middle schools to learn how to teach middle school students, and teachers are sent to enterprises to take shift and have on-the-job placement, translate materials, files, learn translation, tourism, law, international trade so as to serve economic development in southwest area. In recent years, the number of double-qualified teachers has been increasing due to the sound policy of LSNU and teaching staff's endeavour.

\section{Conclusion}

After National Standard and Normal Major Certification were issued, by taking LSNU as a case study, this paper aims to find out the effective means to reconstruct application-oriented talents cultivation system. The study of this paper is conducive to optimize practice teaching system and collaborative education, construct application-oriented curriculum system and train double-professional teachers.

This paper reorganizes the transformation and development of local universities and colleges. Especially, the author of the thesis put forward four measures to solve the current problems. i.e. reconstruct application-oriented talents cultivation system, optimize practice teaching system and collaborative education, construct application-oriented curriculum system and train double-professional teachers.

The author hopes that the measures proposed in the paper will be helpful to local normal universities and thus offer an insight for those colleges and universities that are still striving for transformation and reform.

\section{Acknowledgement}

This paper is supported by a grant from teaching reform project of Leshan Normal University "Exploration and 
Practice of Application-oriented Talents Cultivation System in Local Universities and Colleges under the Background of New National Standard and Major Certification” (Project No.: JG2018-2-35).

\section{References}

Hu, H. Y. (2018). Exploration and Practice of Applied Talent cultivating in Fujian Province. Journal of Minnan Normal University (Philosophy and Social Sciences), 1, 132-136.

Liu, H. W. (2011). Exploration and Practice of the Approach to Applied Translation Talents Cultivating. Electric Power Education in China, 28, 194-195.

Wang, X-G. (2017). Demand-oriented Integration of Production and Study: Exploration and Practice of the Collaborative Education in Local Colleges and Universities. Application-Oriented Higher Education Research, 2(1), 23-26.

Wu, Y., \& Zhang, Y. H. (2016). The Exploration of College-enterprise Cooperation Models for English Majors of Application-oriented Colleges-A Case Study of Translation Cooperation. Journal of Hubei University of Education, 33(7), 30-33.

Yang, J. W., Liang, A. H., \& Yang, Y. (2017). On Development of Educational Programs in Newly-founded Universities-Based on Practice of Sichuan Tourism University. Journal of Sichuan Tourism University, 6, $1-5$

Yun, G. W. (2012). The Exploration and Practice of Applied Talents Cultivation Based on "Engineering with a Big E." Advanced Materials Research, 11, 2270-2273. https://doi.org/10.4028/www.scientific.net/AMR. 591-593.2270

Zeng, D. Q. (2003). Rogers' Humanistic Educational Thought and Its Significance. Journal of Sichuan Normal University (Social Sciences Edition), 30(1), 43-48.

Zhou, J. C., Tong C. Q., \&Jiang, X. R. (2018). Exploration and Practice of Applied Talent Training System of English Related Majors in Local Normal Universities. Joournal of Lilaoning Institute of Science and Technology, 20(4), 77-79.

\section{Copyrights}

Copyright for this article is retained by the author(s), with first publication rights granted to the journal.

This is an open-access article distributed under the terms and conditions of the Creative Commons Attribution license (http://creativecommons.org/licenses/by/4.0/). 